\title{
Diversity, Unity, and Global Citizenship Education: A Case Study in Community Outreach Program in Indonesia
}

\author{
Juliana Anggono ${ }^{1,3,}$, Resmana Lim $^{2,3}$, Frans Limbong ${ }^{3}$, Herry Christian Palit ${ }^{4}$, and \\ Poedi Soenarjo Wartono ${ }^{3}$ \\ ${ }^{1}$ Department of Mechanical Engineering, Petra Christian University, Jalan Siwalankerto 121-131, \\ Surabaya 60236, Indonesia \\ ${ }^{2}$ Department of Electrical Engineering, Petra Christian University, Surabaya 60236, Indonesia \\ ${ }^{3}$ Institute for Research and Community Outreach, Petra Christian University, Surabaya 60236 \\ ${ }^{4}$ Department of Industrial Engineering, Petra Christian University, Surabaya 60236, Indonesia
}

\begin{abstract}
Community Outreach Program is an established international service-learning program which has been around for $22 \mathrm{yr}$. The program offers an inter-discipline activity set in an international atmosphere to connect the academic theories with the actual social life and problems in the less developed rural community in East Java Province, Indonesia. There have been students from 16 university partners from 10 different countries ever participating in the program. Studies from the observations and opinions by the university partners claimed that COP has had an impactful outcomes in students' learning in the areas of diversity awareness, citizenship, and values development. The first study in 2009 on students' expectations in participating in COP reported that the students were aware that joining COP would expose them in diversity through working along with international friends and the community in the village. In this current study, 90 reflection books of COP 2015 Asian participants from Japan, Hong Kong, South Korea, and Indonesia were further studied to test and evaluate how COP as a service-learning program has provided an education setting to educate caring and responsible citizens, who were open to other cultures, and respectful of differences. Students' responses affirmed the positive effects of COP on the acceptance of diversity and sense of civic responsibility.
\end{abstract}

Key words: Citizenship education, community outreach program, diversity, service-learning.

\section{Introduction}

Every higher education institution in Indonesia has to engage in three activities of education, research, and community service. Higher education institutions are inseparable parts of the community and are established to meet society's needs and problems not only locally but also nationally and even globally. Students need to develop the knowledge, attitudes, and

${ }^{*}$ Corresponding author: julianaa@petra.ac.id 
skills that will enable them to identify the society's needs and problems so that they have the contribution to function as citizens in a global society. Increased attention to the need to grow the social responsibility and citizenship skills of students has urged Petra Christian University (PCU) to initiate an international service-learning (S-L) named Community Outreach Program (COP) in 1996. COP is a community service-learning(CSL) which has been defined as "a form of experiential learning where there is a collaboration between students and faculty with communities to address problems and issues, simultaneously gaining knowledge and skills and advancing personal development”. Ideally, S-L is a learning laboratory available to students, through them, greater knowledge and insights would be gained, having an impact on what is taught [1]. It is an academic program which link community service to course work and the students reflect on their service so that it furthers their understanding of course material [2].

Majority of students from Petra Christian University come from economically comfortable background. The worlds in which students grow up prior to entering university have little experience with diversity. They live life comfortably and their parents might be of dual carreer couples who find much less energy to go out for a call of engagement for some transformation of society. Therefore these young generation seldom has an intensive interaction with a diverse cultural mix particulary the overseas friends as well as less opportunities for them to meet people from less developed area in the villages. S-L program through COP expose students to differences among people along class, race, ethnicity, gender, age, religion, and other social dimensions. COP also provides an excellent education program in which students are part of the community involvement together with their international peers toparticipate effectively in public life and prepare them to be full citizens. They will learn from their peer as well as from the community.

In its $20^{\text {th }}$ anniversary of COP in 2016, the total number of students who had participated was 2684 students, consisting of 1557 students were from overseas and 1127 students from PCU. In 2016, there were 193 students comprising of 137 overseas and 56 Indonesian students joined the program. Those 137 overseas students and 56 Indonesian students were located in six sub-villages in Mojokerto Regency hence there were around 32 students live in each of the sub-village. This diverse group of students from eight to nine nationalities including the local villagers who majority are Moslems created a rich cultural mix of a mini world in the village (Figure 1). It is firmly believed that including students in the community involvement are necessary conditions to develop in them capable global citizens with an intercultural competent with the ability to act in the world and for the world.

First study on COP in 2009 shows that the highest expectation in joining COP of the majority of students both from Indonesia and overseas was developing their social skills, i.e. relate to other people. The students were aware that by joining COP, they would be exposed to diversity and would meet diverse individuals either within their teamwork or the village community. In this current research, the authors studied from the reflection books of 90 students from Asia (Hong Kong, Japan, South Korea, and Indonesia) who joined COP in 2016 [3]. These students were in teams that were well balanced in terms of nationalities, religions, and past community experience so that it would help to test and further evaluate how COP as a S-L program has provided an education setting to educate caring and responsible citizens, who have diversity awareness, and respectful of human dignity and differences. 


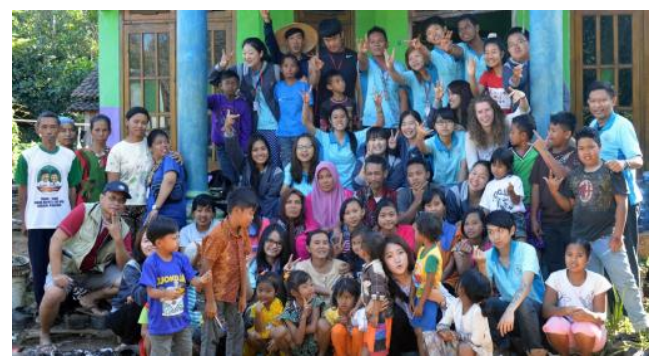

(a)

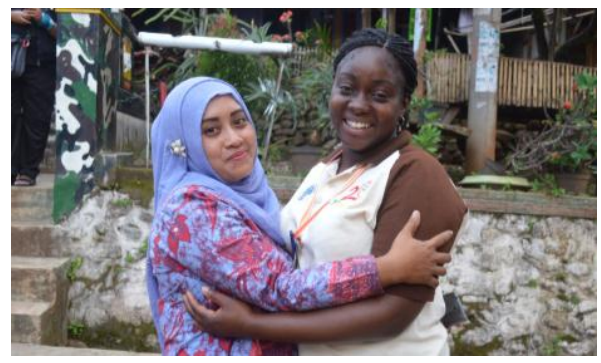

(b)

Fig. 1. (a) A group of COP participants 2016 who was placed at Nawangan village had a photo session with the villagers and (b) Ms. Sri, the head of Gumeng village embraced a participant from the Netherlands.

\subsection{About COP}

The need for interculturally competent professionals and service leaders urges universities to provide education to enable their students to to think, judge, care and act responsibly in a continually changing society. Social problems need to be addressed through an interdisciplinary approach, therefore a platform is necessary to connect knowledge from different academic disciplines and diverse social aspects, to learn from each other's best practices and to apply knowledge in different settings to achieve a better world. Servicelearning through COP precisely prepares students with softskills and characters needed in order to succeed in the future world and to achieve the mission described above. These include a sense of social responsibility, subject related knowledge, as well as skills and competencies such as social competence, communication skills, organization skills, problem-solving skills, and research skills. In an interview in the celebration of $20^{\text {th }}$ anniversary of COP, Rolly Intan, President of PCU said "As future leaders, the students need emotional and spiritual intelligence besides intellectual aptitude. The students need direction and purpose through this life voyage." He believes that by joining the COP, the participants' journeys of life will be transformed to reach their purposes [4].

COP is held on a semester break of July to August every year. Students are prepared in their home universities prior to the program. At PCU, COP requires nearly one year preparation in the aspects of i) selection of the location, in this case is searching for deprived villages, ii) recruiting the students as participants, as well as iii) the proposed development programs for the village. Preparation activities also include conducting one semester preparatory class consisting of 12 meetings, jointly with inviting and communicating with the partner universities, local government as well as the nongovernmnetal organizations. Figure 2 shows the stages of $1 \mathrm{yr}$ preparation of COP. A group of students who are appointed as the group leaders are directed to the village to do a survey for data collection on the village's potentials, its demography, infrastructure, as well as the problems and needs. Those data are important for their group discussion to result in a proposed program. The overseas members of the group are also part of the group discussion via online using social media. At this stage, COP participants learn to observe, analyze, and make sense of the data regarding the condition and potential of the village. They also try to recognize and solve the current local problems by considering several alternatives based on their study of the local surroundings and potential. They finalise the planned program for the village when all the group members meet up as a full team one day before the departure to the village. 


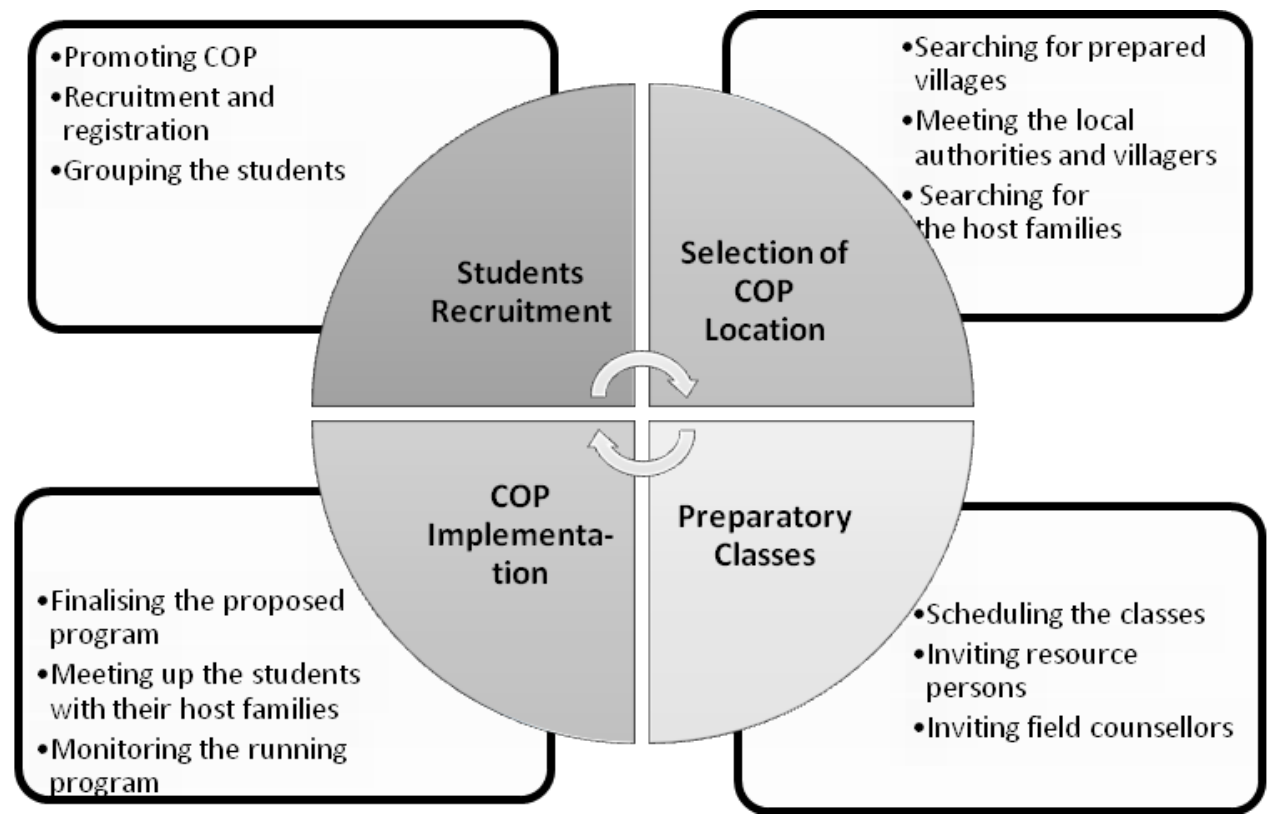

Fig. 1. Stages of COP preparation.

Implementation of COP requires students to live in the selected villages for three to four weeks. Students live with the local families in their homes. Thus the students live and feel the host culture including the warmth and the friendliness through daily interaction and meals with their host family. Figure 3 shows the condition of a village, i.e.: the road, housing, and communal toilets as well as the host family they lived with.

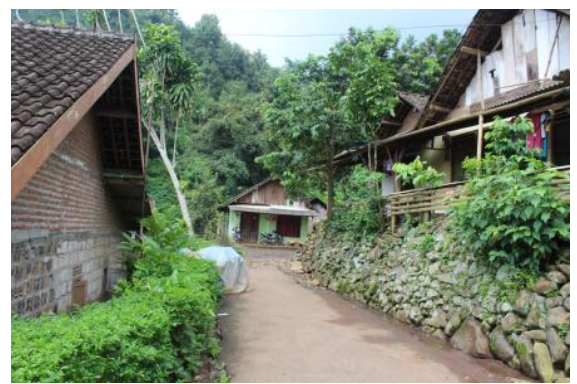

(a)

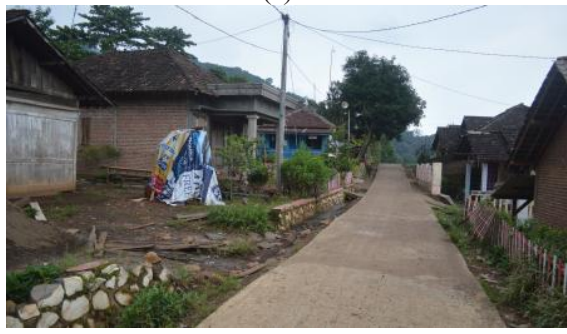

(c)

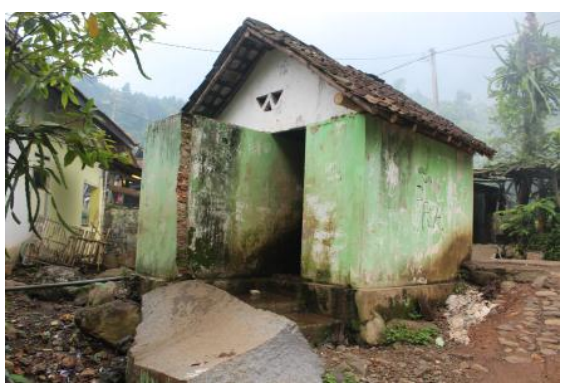

(b)

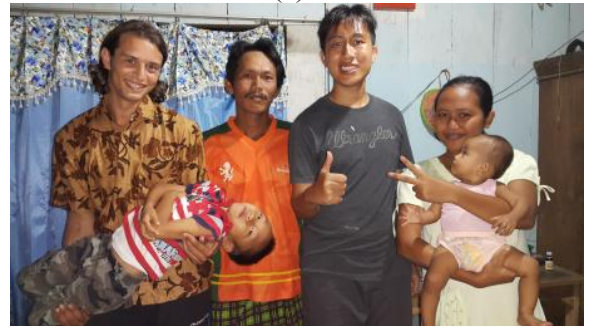

(d)

Fig. 2. Road, housing, and communal toilets condition at COP locations (a), (b) in Jembul village and (c) in Siman village and (d) Participants from Hong Kong, Indonesia, and the Netherlands took a picture with their host family on the last day of COP. 
For the students, living with the villagers who live very simply with much less facility compared with the urban life, have clean water shortage, and no toilets in their houses, they are also taught not only to sympathize but also to empathize. In this case, COP helps in the transformation of characters. Serving the community during COP enables students not only directly apply science, technology, and arts that they learn from the classroom but also the sociological concepts and theories: social problems, race relations, poverty, and rural problems [5]. The participation of the community during implementation of the program is also very important since it will help the villagers to recognize and solve their own problems independently in the future. In other words, through COP, students help the community in solving and handling emergent problems.

\subsection{Global citizenship education}

No society is immune from the influences of globalization. It is changing the very fundamentals of human relations and social life. Globalization affects every aspect of communities, including beliefs, norms, values, and behaviors, as well as business and trade. There is an increase in diversity in in most nation-states due to worldwide migration; this is forcing nations to rethink citizenship and citizenship education. National boundaries are wearing away because millions of people live in several nations and have multiple citizenships thus local demographicsare markedly changing. [6] The need for interculturally competent professionals and service leaders urges universities to prepare their students with a whole person approach education that enables them to think, judge, care and act responsibly in a continually changing society and wider world. It is also very important for higher education institutions to develop capable global citizens that can use of knowledge wisely for the improvement of the world.

Global citizenship refers to a sense of belonging to a broader community and common humanity. It highlights the interdependency in political, economic, social and cultural along with interconnectedness between the local, the national and the global [7]. Growing interest in global citizenship has resulted in increased attention to the global dimension in citizenship education as well, and the implications for policy, curricula, teaching and learning. The basis for defining global citizenship education goals, learning objectives and competencies, as well as priorities for assessing and evaluating learning is on aspects from all three domains of learning: cognitive, socio-emotional and behavioural (Figure 4).

\section{Cognitive:}

To acquire knowledge, understanding and critical thinking about global, regional, national and local issues and the interconnectedness and interdependency of different countries and populations.

Socio-emotional:

To have a sense of belonging to a common humanity, sharing values and responsibilities, empathy, solidarity and respect for differences and diversity.

Behavioural:

To act effectively and responsibly at local, national and global levels for a more peaceful and sustainable world.

Fig. 3. Core conceptual dimensions of global citizenship education [4]. 
Global citizenship education aims to be transformative, building the knowledge, skills, values and attitudes that learners need to be able to contribute to a more inclusive, just and peaceful world. Guidance on moral values and personal development are essential preconditions of citizenship, therefore global citizenship education should be developed from early education. From the very beginning children should learnself confidence and socially and morally responsible behaviour both in and beyond the classroom whenever and wherever they work or play in groups or participate in the affairs of their communities, both towards those in authority and towards each other. Through learning and discussion, children are already forming concepts offairness, and attitudes to the law, to rules, to decision making, to authority, to their local environment and social responsibility etc. Learning about and becoming helpfully involved in the life and concerns of their communities, including learning through community involvement and service to the community are the second way of applying global citizenship education. COP as an international S-L program offers global citizenship education in which students from various disciplines such as engineering, architecture, social studies, environmental studies, geography, history, religious education, science, music and artscan build capacity for selfexpression, develop a sense of belonging and facilitate understanding of and dialogue with people from different cultures; they also play a central role in critical inquiry and analysis of social and other issues. Figure 5 shows several program implementations during COP.

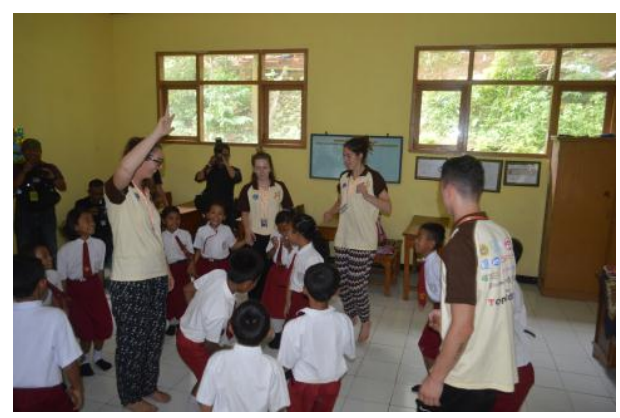

(a)

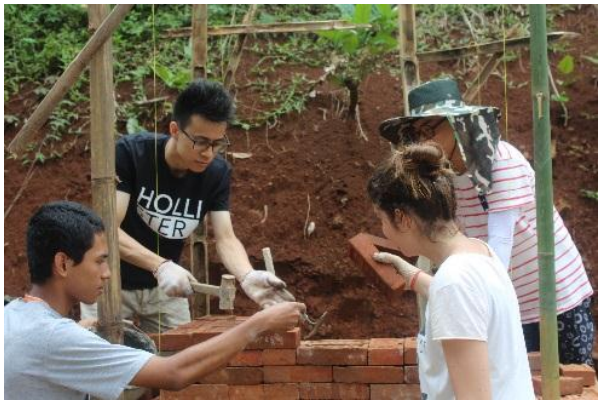

(b)

Fig. 4. Students' activities during COP (a) teaching at local elementary school and (b) in physical program: building the village's entrance gate.

\section{Methodology}

To measure the extent of how COP can provide global citizenship education to the students, a study on their reflection journals was carried out. The number of the journals studied were 90 books belonged to the students who came from four different countries in Asia, i.e. 21 journals owned by students from Hong Kong; seven journals were from Japanese students, 21 journals from South Korean students; and 41 journals fromIndonesian students. The Asian students were chosen to represent sampling of students who come from big cities and most of them grow up in fairly homogeneous neighborhoods, segregated typically by race and class. S-L experiences through COP expose students to a wide range of class, race and ethnic, and religions in the community with which they are likely to have had little previous contact.

\subsection{Design of the reflection journal}

Reflection journals were designed with open questions and the questions were interrelated in three period of time, i.e. pre-departure to the village, at mid COP, and at the end of COP. 
At each period, students reflected and answered only a set of questions for that particular stage. In this research, it was focused on the students' answers on their expectation to achieve by participating in COP (prior to COP), what they feel (mid COP) and what they have learned and achieved (end of COP). Table 1 shows some of the questions on the students' reflection journals.

Table 1. Open questions on students' reflection journals.

\begin{tabular}{ll}
\hline \multicolumn{1}{c}{ Period } & \multicolumn{1}{c}{ Questions } \\
\hline Pre-departure to the village & What do you expect to learn or achieve by participating in a COP? \\
Mid COP & What do you feel until this mid period? \\
End of COP & a) Are your expectations as in pre-program achieved? Why? \\
& b) Did you accomplish your projects goal? Please explain? \\
\hline
\end{tabular}

\section{Results and discussion}

\subsection{Students' responses}

Ninety students' responses from their reflection journals on their expectation by articipating in COP and what they had learned were collected and grouped into five classifications, i.e.: open to different culture, academic, self development, care for villagers and spiritual growth. These Asian young people when they decided to join COP in the rural areas in Indonesia knew their goals. Table 2 shows that mainly they wanted to learn about different culture particularly from the locals. The locals that the students lived and worked with during COP were Javanese people, speaking Javanese language and their religion background was Moslems. Majority of them were farming workers and had low level of education. Many responses also expected to learn from cultural difference among the participants as the COP could attract nine nationals to take part including students from the Netherlands, United Kingdom, Taiwan, China, and Singapore.

These students also show the awareness of the importance of communication skill in regards with the language skill, either skills in English or Indonesian language speaking to enable them to interconnect with both international participants as well as the villagers.Similar finding on developing communication skill through learning languages (English and Bahasa Indonesia) was reported in the first study on COP [3]. Although the responses about improving communication skill were classified in the group of self development, however those responses were interrelated with the openness to different culture.

As mentioned previously that global citizenship education is based on the three domains of learning - the cognitive, socio-emotional and behavioural. These correspond to the four pillars of learning described in the report 'Learning: The Treasure Within': Learning to know, to do, to be and to live together. [8]

i) Cognitive: knowledge and thinking skills necessary to better understand the world andits complexities.

ii) Socio-emotional: values, attitudes and social skills that enable learners to developaffectively, psychosocially, and physically and to enable them to live together with othersrespectfully and peacefully.

iii) Behavioural: conduct, performance, practical application and engagement. 
Table 2. Students' responses obtained from their reflection journals

\begin{tabular}{|c|c|c|c|c|c|c|c|}
\hline \multicolumn{2}{|c|}{ Response } & Students Answers & HK & JPP & $\mathbf{K R}$ & ID & TOTAL \\
\hline \multirow{4}{*}{\multicolumn{2}{|c|}{ Open to Different Culture }} & $\begin{array}{l}\text { Experience different part of } \\
\text { lifestyle }\end{array}$ & 5 & 0 & 1 & 3 & 9 \\
\hline & & $\begin{array}{l}\text { Learn about cultural } \\
\text { differences }\end{array}$ & 4 & 1 & 7 & 19 & 31 \\
\hline & & $\begin{array}{l}\text { Learn about local culture of } \\
\text { the villagers }\end{array}$ & 15 & 5 & 6 & 16 & 42 \\
\hline & & $\begin{array}{l}\text { Meet new friends from } \\
\text { different countries }\end{array}$ & 3 & 0 & 7 & 6 & 16 \\
\hline \multirow{13}{*}{$\begin{array}{c}\text { Self } \\
\text { Development }\end{array}$} & \multirow{4}{*}{$\begin{array}{l}\text { Interpersonal } \\
\text { Skill }\end{array}$} & $\begin{array}{l}\text { Learn to work with people } \\
\text { from different background }\end{array}$ & 3 & 0 & 2 & 6 & 11 \\
\hline & & $\begin{array}{l}\text { Learn to live with other } \\
\text { people }\end{array}$ & 0 & 0 & 1 & 0 & 1 \\
\hline & & $\begin{array}{l}\text { Learn about time } \\
\text { management }\end{array}$ & 1 & 0 & 0 & 3 & 4 \\
\hline & & Help to choose future career & 2 & 0 & 2 & 1 & 5 \\
\hline & \multirow{3}{*}{$\begin{array}{l}\text { Communication } \\
\text { Skill }\end{array}$} & $\begin{array}{l}\text { Want to learn speaking } \\
\text { english }\end{array}$ & 1 & 0 & 3 & 1 & 5 \\
\hline & & $\begin{array}{l}\text { Want to learn indonesia } \\
\text { language }\end{array}$ & 1 & 0 & 1 & 0 & 2 \\
\hline & & $\begin{array}{l}\text { Improve communication } \\
\text { skill }\end{array}$ & 7 & 1 & 1 & 11 & 20 \\
\hline & \multirow{3}{*}{ Openness } & Learn about tolerance & 3 & 1 & 1 & 6 & 11 \\
\hline & & $\begin{array}{l}\text { Learn to be more open } \\
\text { minded }\end{array}$ & 4 & 1 & 1 & 9 & 15 \\
\hline & & $\begin{array}{l}\text { Learn to cooperate with } \\
\text { teammates }\end{array}$ & 4 & 0 & 0 & 3 & 7 \\
\hline & \multirow{3}{*}{ Adaptability } & $\begin{array}{l}\text { Develop new ability with } \\
\text { working in unfamiliar and } \\
\text { different workplace }\end{array}$ & 1 & 0 & 0 & 3 & 4 \\
\hline & & Get new experience & 1 & 2 & 2 & 10 & 15 \\
\hline & & $\begin{array}{l}\text { Learn to adapt in different } \\
\text { environment }\end{array}$ & 2 & 0 & 2 & 5 & 9 \\
\hline \multicolumn{2}{|c|}{ Academic } & $\begin{array}{l}\text { Assist in majoring that has } \\
\text { been chosen }\end{array}$ & 2 & 1 & 2 & 6 & 11 \\
\hline \multirow{4}{*}{\multicolumn{2}{|c|}{ Care for Villagers }} & $\begin{array}{l}\text { Help improve the villagers' } \\
\text { life }\end{array}$ & 4 & 1 & 1 & 10 & 16 \\
\hline & & $\begin{array}{l}\text { Learn to care for other } \\
\text { people }\end{array}$ & 0 & 0 & 2 & 4 & 6 \\
\hline & & Want to volunteering & 2 & 1 & 5 & 0 & 8 \\
\hline & & $\begin{array}{l}\text { Learn to use own skills for } \\
\text { other people }\end{array}$ & 2 & 0 & 0 & 3 & 5 \\
\hline \multirow{3}{*}{\multicolumn{2}{|c|}{ Spiritual Growth }} & $\begin{array}{l}\text { More appreciation toward } \\
\text { life }\end{array}$ & 2 & 0 & 1 & 4 & 7 \\
\hline & & Learn the meaning of life & 2 & 0 & 0 & 0 & 2 \\
\hline & & In relationship with God & 1 & 0 & 0 & 4 & 5 \\
\hline
\end{tabular}


Table 3. Domains of Learning that COP Can Provide for Global Citizenship Education

\begin{tabular}{|c|c|c|c|c|c|}
\hline \multirow[b]{2}{*}{ Response } & \multirow{2}{*}{\multicolumn{2}{|c|}{ Students Answers }} & \multicolumn{3}{|c|}{ Domains of Learning } \\
\hline & & & Cognitive & $\begin{array}{c}\text { Socio- } \\
\text { emotional }\end{array}$ & Behavioural \\
\hline $\begin{array}{l}\text { Open to } \\
\text { Different } \\
\text { Culture }\end{array}$ & $\begin{array}{l}\text { Experience diffe } \\
\text { Learn about cultı } \\
\text { Learn about loca } \\
\text { villagers } \\
\text { Meet new friend } \\
\text { countries }\end{array}$ & $\begin{array}{l}\text { al part of lifestyle } \\
\text { culture of the } \\
\text { from different }\end{array}$ & & & \\
\hline & $\begin{array}{l}\text { Interpersonal } \\
\text { Skill }\end{array}$ & $\begin{array}{l}\text { Learn to work with } \\
\text { people from different } \\
\text { background } \\
\text { Learn to live with } \\
\text { other people } \\
\text { Learn about time } \\
\text { management } \\
\text { Help to choose } \\
\text { future career }\end{array}$ & & & \\
\hline $\begin{array}{c}\text { Self } \\
\text { Develonment }\end{array}$ & $\begin{array}{l}\text { Communication } \\
\text { Skill }\end{array}$ & $\begin{array}{l}\text { Want to learn } \\
\text { speaking English } \\
\text { Want to learn } \\
\text { Indonesia language } \\
\text { Improve } \\
\text { communication skill }\end{array}$ & & & \\
\hline & Openness & $\begin{array}{l}\text { Learn about } \\
\text { tolerance } \\
\text { Learn to be more } \\
\text { open minded } \\
\text { Learn to cooperate } \\
\text { with teammates }\end{array}$ & & & \\
\hline & Adaptability & $\begin{array}{l}\text { Develop new ability } \\
\text { with working in } \\
\text { unfamiliar and } \\
\text { different workplace } \\
\text { Get new experience } \\
\text { Learn to adapt in } \\
\text { different } \\
\text { environment }\end{array}$ & & & \\
\hline Academic & Assist in majorin & that has been chosen & & & \\
\hline $\begin{array}{l}\text { Care for } \\
\text { Villagers }\end{array}$ & $\begin{array}{l}\text { Help improve the } \\
\text { Learn to care for } \\
\text { Want to voluntee } \\
\text { Learn to use own }\end{array}$ & $\begin{array}{l}\text { villagers' life } \\
\text { ther people } \\
\text { ing } \\
\text { skills for other people }\end{array}$ & & & \\
\hline Spiritual Growth & $\begin{array}{l}\text { More appreciatio } \\
\text { Learn the meanir } \\
\text { In relationship w }\end{array}$ & $\begin{array}{l}\text { toward life } \\
\text { of life } \\
\text { h God }\end{array}$ & & & \\
\hline
\end{tabular}

The responses related to the openness to different culture as well as self development in communication skill can demonstrate the key learning outcomes and attributes in the domain of socio-emotional which shows a need to develop and apply values, attitudes and skills to manage and engage with diverse groups and perspectives. From social psychological research on race relations, it was learned that when people are placed in contexts in which they can work together for a common good, positive inter-group relations are most likely to emerge [9]. S-L programs promote such positive interactions and provide 
a supportive context for their development and interpretation [10, 11]. Table 3 shows the domains of learning that COP can provide for global citizenship education.

Figure 6 shows the groupings from Table 2 in a bar chart. It is known from the chart that the highest number responses were related with self development (109 responses or $41 \%$ ) then followed with the openness to different culture or background (98 responses or $37 \%$ ). The other three groups of responses were academic (11 responses or $4 \%$ ), caring (35 responses or $13 \%$ ), and spiritual growth aspects (14 responses or $5 \%$ ).

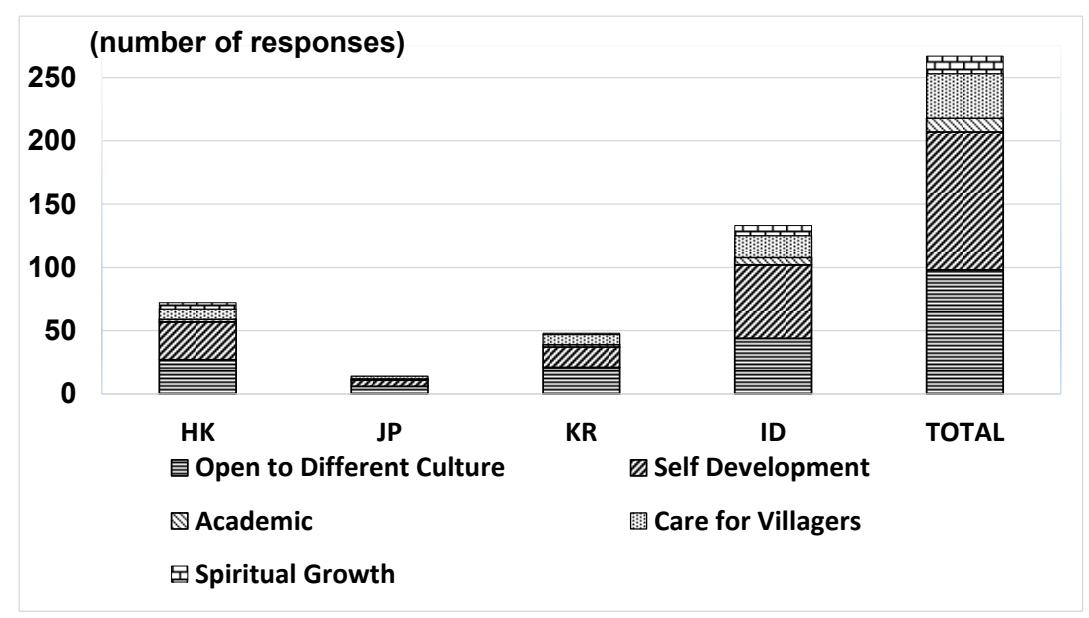

Fig. 5. Distribution of students' responses on their goals as COP participants.

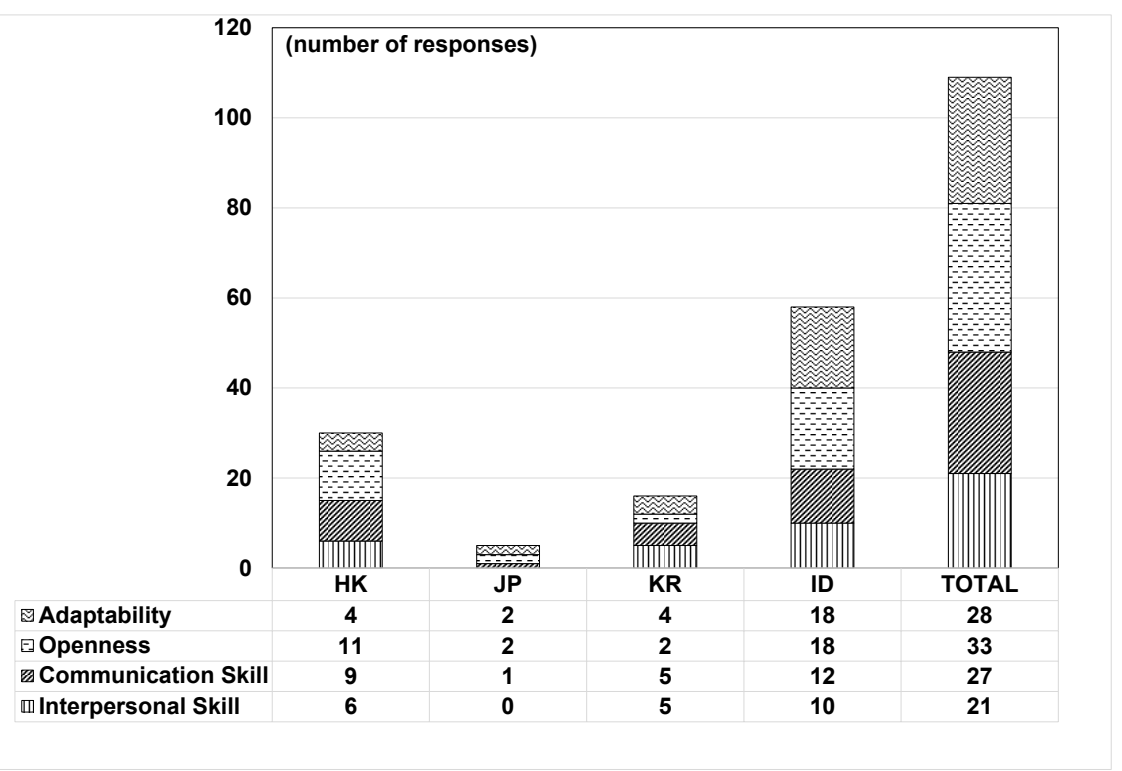

Fig. 6. Distribution of students' responses about self development.

Figure 7 counts the quantity of each response group, particularly on the response about self development within one country to enable a comparative study to be made on these young people'sexpectations and experiences from COP. Being open to other culture: to learn about tolerance, to be open minded, and to cooperate with team mates got the highest responses from three nationals except the Koreans. This highest response shows a good signal that COP was able to help students develop respect for differences and diversity. The 
Korean participants wished and gave higher responses on the communication and interpersonal skills.

Figure 8 lists the distribution of one response among the other responses within one country. The distribution shows that participants from Hong Kong and Indonesia expected to learn and gain self development when joining COP. In the case for Japanese and Koreans, they expected to learn more on being open to different culture. It's hard to have those two responses: open to different culture and self development separated as they might direct to the same purpose to get connect and open to different cultures (see responses in Table 2).

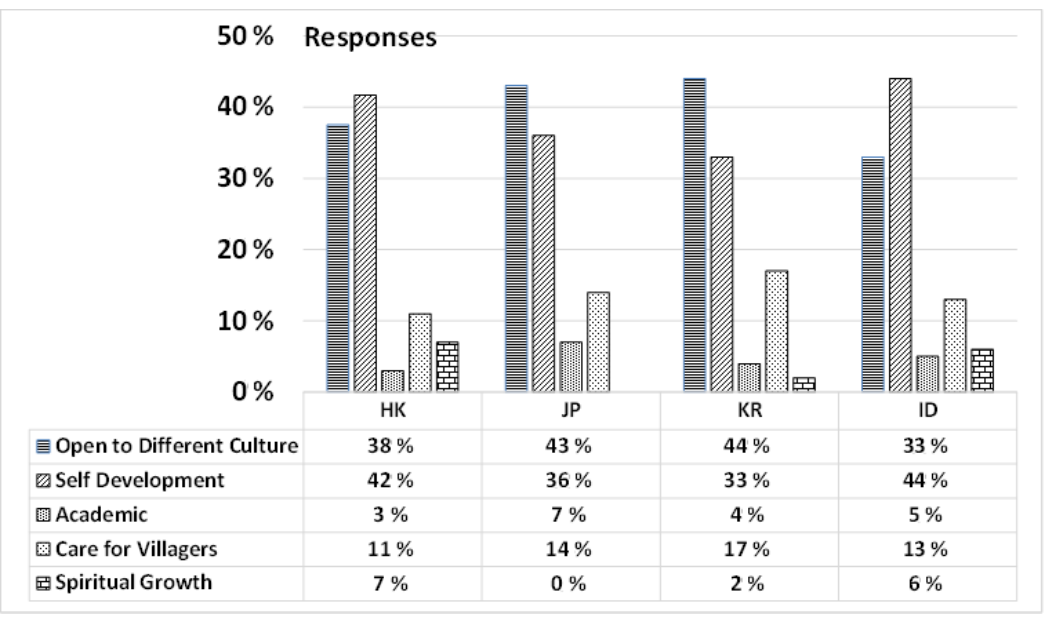

Fig. 7. Expectation and experiences of COP participants from different Asian countries.

\subsection{The learning environment: students' activities during COP}

To achieve effective global citizenship education, it requires critically safe, inclusive and engaging learning environments. Such environments enhance the experience of learning, support different types of learning, value the existing knowledge and experience of learners and enable the participation of learners from a diversity of backgrounds.

COP is designed a project-based learning which involves students working in a teamwork to participate in projects. It provides opportunities for a collaborative work, experiential learning, and it uses a service-learning approach. Each day they make a plan on what to do and who will involve and an evaluation at the end of the day. Each one participates in different program implementation and they also invite the villagers to participate in the program when they can. Therefore in COP, the participants feel valued and included, and foster collaboration, healthy interaction, respect,cultural sensitivity and they will learn that other values and skills are needed to live in a diverse world.

The width and depth of global citizenship education through COP have been evidenced through the growing of empathy, solidarity and respect to the diversity. COP helps in shaping a friendship and family bond among the team mates as well as with the host family. Many overseas participants who have holiday in Indonesia making arrangement to visit their friends and the host family they used to live during COP (Figure 9). As quoted from Benjamin Disraeli, a British politician (1804 to 1881): "seeing much, suffering much, and studying much, are the three pillars of learning," COP provides such a learning environment which gives students a lot of experiences to see, suffer, and study much so that they learn to live together with others respectfully and peacefully. 

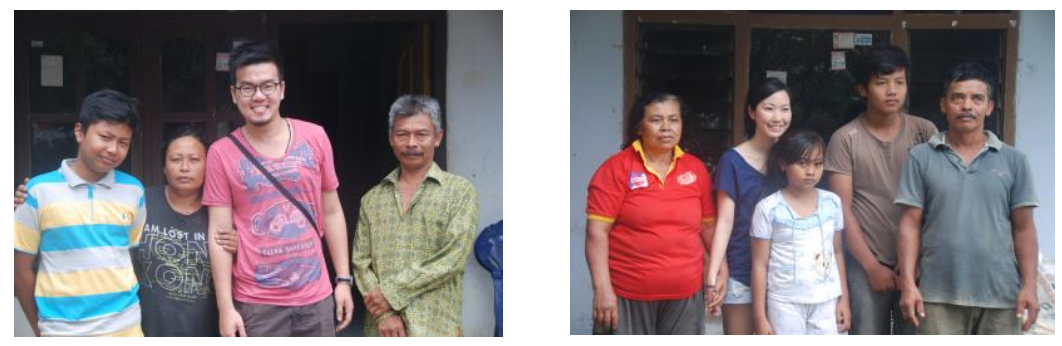

Fig. 8. A visit to meet their host family that they used to live with during participating in COP.

\section{Conclusions}

The study from the students' responses on their reflection journals demonstrates that COP as community service-learning has provided an education settingin which interaction in a multiracial, multiethnic, and different religion setting that helps develop and apply values, attitudes and skills to manage and engage with diverse groups and perspectives. Furthermore, the program has a civic focus. It offers a pathway to educate caring and responsible citizens to contribute for the improvement of the community.

Authors were grateful with the assistance of Suryani Chandra and Thomas Benmetan in gathering and grouping the data

\section{References}

1. W.R. Ramsay. Service learning memories and perspectives. In: Where's the wisdom in service-learning. R. Shumer (Eds). Charlotte: IAP (2017). pp. 46. http://www.infoagepub.com/assets/files/fm/p58f0e436bfcd6/9781681238661 FM.pdf

2. R. Bringle, J. Hatcher. Michigan Journal of Community Service Learning, 2, 1:112-122 (1995). https://quod.lib.umich.edu/m/mjcsl/3239521.0002.111/--service-learningcurriculum-for-faculty?view=image

3. J. Anggono, Y.B. Cahyono, N.P., Adhi, F. Pasila. International service-learning through community outreach program in villages in Kediri-east JAVA: a study on students' reflection journals. Service-Learning Studies Series No. 4 (ICU ServiceLearning Centre, Japan, 2009).

https://www.researchgate.net/publication/43649723_International_ServiceLearning_through_Community_Outreach_Program_in_Villages_in_KediriEast Java_A_Study on_Students' Reflection_Journals in_Lessons from_ServiceLearning in Asia Results of Collabora

4. F. Lesmana, Y.B. Cahyono. COP misi yang tak putus aksi yang tak pupus [COP Unstoppable mission, unbreakable action]. Surabaya: Petra Press (2016). p. 71.

5. C.M. Musil. Educating students for personal and social responsibility: the civic learning spiral. In: Civic engagement in higher education: concepts and practices. T. Ehrlich and B. Jacoby (Eds.). San Francisco: Jossey-Bass (2009). pp. 62-63

https://keycenter.unca.edu/sites/default/files/Jacoby_CivicEngagement_31.pdf

6. S. Castles, A. Davidson. Citizenship and migration: globalization and the politics of belonging. New York: Routledge (2000). pp. 1-24

https://books.google.co.id/books/about/Citizenship_and_Migration.html?id=ER6x5m2 UZoYC\&redir_esc $=y$ 
7. UNESCO, Global citizenship education: topics and learning objectives [Online] from http://unesdoc.unesco.org/images/0023/002329/232993e.pdf (2015). [Accessed on 11 May 2018]

8. J. Delors, I. Al Mufti, I. Amagi, R. Carneiro, F. Chung, B. Geremek, et al. Learning: the treasure within [Online] from http://unesdoc.unesco.org/Ulis/cgibin/ulis.pl?catno $=102734 \& \mathrm{gp}=0 \&$ lin $=1 \& 11=2$ (1996). [Accessed on 3 January 2018]

9. G. Allport, The nature of prejudice. Cambridge, MA: Addison-Wesley (1954). https://books.google.co.id/books/about/The Nature of Prejudice.html?id=TIVTx4GU B1AC\&redir_esc $=$ y

10. H. Berry. Service-Learning in international and intercultural settings. In: Combining service and learning. J. Kendall and Associates (Eds). Raleigh, NC: National Society for Internships and Experiential Education (1990). pp. 311-313. https://www.amazon.com/Combining-Service-Learning-Resource-

Community/dp/0937883085

11. J.S. Permaul. Community service and intercultural education. In: Rethinking tradition. T. Kupiec (Eds). Providence, RI: Education Commission for the States and The Campus Compact (1993). pp. 83-88. 